\title{
Evidence of interspecies transmission of pathogenic Leptospira between livestock and a domestic cat dwelling in a dairy cattle farm
}

\author{
Javier OJEDA ${ }^{1)}$, Miguel SALGADO ${ }^{2)}$, Carolina ENCINA ${ }^{2)}$, Camila SANTAMARIA ${ }^{2)}$ \\ and Gustavo MONTI ${ }^{2) *}$ \\ ${ }^{1)}$ Veterinary Clinical Sciences Department, Faculty of Veterinary Sciences, Universidad Austral de Chile, Valdivia, \\ 5090000, Chile \\ 2) Preventive Veterinary Medicine Department, Faculty of Veterinary Sciences, Universidad Austral de Chile, \\ Valdivia, 5090000, Chile
}

\section{J. Vet. Med. Sci.}

80(8): 1305-1308, 2018

doi: 10.1292/jvms.16-0361

Received: 21 June 2016

Accepted: 3 June 2018

Published online in J-STAGE:

2 July 2018
ABSTRACT. A domestic cat dwelling in a dairy cattle farm with haematuria was referred for a physical examination. The examination showed no abnormalities therefore complementary exams were performed. Leukocytosis with neutrophilia, monocytosis and hyperproteinaemia were detected. The urine analysis showed a bacterial infection without ultrasound findings. Serological titers to Leptospira interrogans serovar Pomona and Autumnalis were detected. Molecular analysis demonstrated the presence of Leptospira spp. in urine. The findings were consistent with subclinical leptospirosis. The cattle herd had evidence of Leptospira infection. The microbiological exams confirmed the presence of the Leptospira spp. in urine and serum. According to the evidence presented in this study, cats that dwell within a dairy farm could play a role in the Leptospira infection epidemiologically. The importance of feline leptospirosis must be evaluated with leptospirosis control in livestock.

KEY WORDS: antibiotic treatment, feline, infection, Leptospira

Leptospirosis is a ubiquitous zoonotic infectious disease and it is caused by the infection of pathogenic spirochetes belonging to the genus Leptospira [11]. Leptospirosis is a systemic disease of humans and domestic animals, mainly dogs, cattle and swine, characterised by fever, renal and haepatic insufficiency, pulmonary manifestations and reproductive failure [1, 11, 20].

Canine leptospirosis has been extensively described [19] while clinical reports of leptospirosis in cats are rare [3, 8, 9]. The presence of antibodies in cats has suggested that cats can be infected with leptospires, but clinical signs seem to be infrequent [4, 8].

It is well established that Leptospira infection in Chile is present both in domestic and wild animals [14, 22-25]. The apparent prevalence (AP) in different domestic animal species is considered high, especially for cattle [16]. Meanwhile, a serological study in cats in Southern Chile, estimated the AP at $8.1 \%$ [4] with contrasting differences in seroprevalences between rural (25\%) and urban $(1.8 \%)$ cat populations.

In Chile, both dogs and cats frequently share environments with cattle but cats are far more likely to live close to cattle than dogs.

The aim of the present study was to provide both clinical and microbiological evidence of Leptospirosis in a cat presenting clinical signs and to clarify the health threat of cats which dwell in close proximity to a dairy cattle herd.

In spring 2014, a one year old, male, domestic shorthair, indoor/outdoor cat dwelling in a dairy cattle farm was referred to the Veterinary Teaching Hospital at the Universidad Austral of Chile.

The cat lived on a dairy farm and had close contact with the cattle herd which had a clinical history of events (before 2014) consistent with Leptospira infection, such as abortion, low conception rate and stillbirth calves. Furthermore, systematic vaccination was not practiced in this herd. The herd consisted of 220 animals of Holstein Friesian breed, located in the Lago Ranco County, Los Rios Region of Chile and corresponded to a semi-extensive dairy operation. Coexistence with other farm animals (domestic and wild) was observed.

This herd had an estimated AP of 66\% using the Microscopic Agglutination Test (MAT). L. interrogans serovar Hardjo and L. interrogans serovar Pomona were the most frequent serovars, and some clinical cases of calves and cows were confirmed by

*Correspondence to: Monti, G.: gustavomonti@uach.cl

O2018 The Japanese Society of Veterinary Science

This is an open-access article distributed under the terms of the Creative Commons Attribution Non-Commercial No Derivatives (by-nc-nd) License. (CC-BY-NC-ND 4.0: https://creativecommons.org/licenses/by-nc-nd/4.0/) 
culture and molecular typing as serovars Hardjo prajitno and Pomona.

The cat owner described a persistent haematuria in the cat for the two months leading up to the examination with no changes in its micturition behaviour and it had no previous illness. It was neither vaccinated nor dewormed. The cat had a frequent rat hunting behaviour. According to the owner the haematuria was considered the main problem.

The physical examination showed no abnormalities and two diagnoses were proposed according to the clinical information and anamnesis: feline low urinary tract disease or active infection with pathogenic Leptospira. To confirm the diagnoses the cat was hospitalised in an isolation cage performing a complete blood count (CBC) with the analysis of clinical biochemistry including ALT, AST, ALP, GGT, total bilirubin, albumin, phosphate, sodium, calcium, potassium, urea and creatinine. Finally, a urine analysis and an abdominal ultrasound of liver, kidney, spleen, bladder and intestines were also performed. In addition, serum was serologically examined against six Leptospira serovars (L. interrrogans serovars Hardjo, Pomona, Canicola, Icterohaemorragiae and Autumnalis and L. borgpetersenii serovar Ballum) using MAT following a standard protocol [16].

Infection status of the patient was conducted through a diagnostic approach based on urine culture together with subsequent molecular confirmation (qPCR) of the positive sample and molecular characterisation of the bacterium [21]. Urine samples were collected via cystocentesis using a $21 \mathrm{G}$ needle attached to $5 \mathrm{~m} l$ syringe. This was performed blind with palpation of the urinary bladder or ultrasound guided.

Two hundred $\mu l$ of urine with four replicates (days $0,12,26$ and 60 after the cat was received in the Hospital) was cultured in EMJH medium at $29^{\circ} \mathrm{C}[6]$ and checked weekly for 12 weeks or until formation of a Dinger ring. Thereafter, a sample of positive culture was submitted for DNA extraction-purification protocol using the High Pure PCR Template Preparation kit (Roche), following the manufacturer instructions. Leptospira presence in positive cultures was confirmed by qPCR.

The DNA templates obtained from the above protocol were analysed in a qPCR system (Roche LightCycler 2.0), using a TaqMan probe and targeting the lipl32 gene (Stoddard y col 2009), which is targeted only for pathogenic Leptospiras species. The amplification mixture for each sample; $0.7 \mu \mathrm{M}$ primers, $0.15 \mu \mathrm{M}$ probe, $10 \mu l$ Master Mix TaqMan universal (Roche) and $5 \mu l$ DNA template, in a total volume of $20 \mu \mathrm{l}$. Samples were amplified with the following program: initial denaturation at $95^{\circ} \mathrm{C}$ for $2 \mathrm{~min}$, followed by 40 cycles of denaturation for $5 \mathrm{sec}$ at $95^{\circ} \mathrm{C}$ and annealing/elongation for $30 \mathrm{sec}$ at $58^{\circ} \mathrm{C}$. The system considered a negative and positive control in order to survey the proficiency of the reaction as well as DNA extraction negative and positive controls.

A template from a positive culture was submitted for molecular characterisation, amplifying the gene $\sec Y$, a housekeeping gene suitable for Leptospira phylogenetic interpretation [2]. A 202 bp product was amplified by conventional PCR in $25 \mu l$ mixture containing $5 \mu \mathrm{l}$ of diluted template (1:100), $0.2 \mu \mathrm{M}$ each primers SecYIVF (5'- GCGATTCAGTTTAATCCTGC-3') and $\operatorname{SecYIV~(5'-GAGTTAGAGCTCAAATCTA-AG-3'),~} 0.625$ U GoTaq Flexi DNA Polymerase in 1X Green Buffer GoTaq (Promega, Madison, WI, U.S.A.), $3.098 \mathrm{mM} \mathrm{MgCl}_{2}, 0.3 \mathrm{mM}$ dNTPs (Promega), and $400 \mathrm{ng} / \mathrm{m} l$ bovine serum albumin (BSA; BioLabs, Ipswich, U.K.). The cycle conditions included an initial denaturation step at $95^{\circ} \mathrm{C}$ for 5 min followed by 40 cycles at $94^{\circ} \mathrm{C}$ for $1 \mathrm{~min}, 57^{\circ} \mathrm{C}$ for $1 \mathrm{~min}$ and $72^{\circ} \mathrm{C}$ for $1 \mathrm{~min}$. and a final elongation step at $72^{\circ} \mathrm{C}$ for $10 \mathrm{~min}$. The PCR products obtained were separated on 1.5\% agarose gel, stained with Gel Red (GelRed, Biotium Inc., Hayward, CA, U.S.A.), excised and purified using a commercial kit (E.Z.N.A ${ }^{\circledR}$ Gel Extraction Kit, Omega Bio-Tek, Norcross, GA, U.S.A.). Amplicons were sequenced by Macrogen Inc. (Seoul, Korea). The consensus nucleotide sequence obtained was compared with the secY gene of Leptospira interrogans serovar Pomona (GenBank accession number KU219481). DNA alignments were done using clustalW tools (http://www.ebi.ac.uk/ Tools/msa/clustalw2).

The complete blood count (CBC) showed a marked leukocytosis (35,600 cells/ $\mu l$ Reference Interval (RI) 5,500-19,500 cells/ $\mu l$ ) with moderate neutrophilia (30,260 cells/ $\mu l$ RI 2,500-12,500 cells/ $\mu l)$ without a left shift and with slight monocytosis $(1,780$ cells/ $\mu l$ RI 100-900 cells $/ \mu l)$, indicative of a chronic inflammatory process. Also a hyperproteinaemia $(9.6 \mathrm{~g} / \mathrm{d} l, \mathrm{RI} 6.0-8.0 \mathrm{mg} / \mathrm{d} l)$ was detected. Red blood cells were normal. The analysis of clinical biochemistry included ALT, AST, ALP, GGT, total bilirubin, albumin, phosphate, sodium, calcium, potassium, urea and creatinine. All clinical biochemistry parameters were normal. The urine showed alteration in $\mathrm{pH}$ ( $\mathrm{pH} 8 \mathrm{RI} 5.5-7.0)$, presence of albumin $(500 \mathrm{mg} / \mathrm{d} l)$, erythrocytes ( $>50$ cells/field), leucocytes $(>100$ cells/ field) and many bacteria were detected. Also granular cylinders and epithelial squamous cells were found to be lacking. The abdominal ultrasound of the liver, kidney, spleen, bladder and intestines did not show any pathological findings. Urinary tract infection was considered to be in accordance with the urinalysis but the moderate leukocytosis with the absence of ultrasound evidence in the bladder or kidneys suggested exploring a further leptospirosis diagnosis.

High antibody titers against serovars Pomona and Autumnalis were detected (1:6,400). The urine of the first sample culture (day0) clearly showed the characteristic Dinger ring after 60 days of culturing, indicative of Leptospira bacterial growth, also confirmed by qPCR targeted lipL32, and no evidence of contamination was observed. All together these findings confirm the leptospiruria, which together with the owner's description, confirmed the disease. ClustalW aligment for $151 \mathrm{bp}$ fragment of secY gene of isolate in this study showed 100\% identity with Leptospira interrogans serovar Pomona strain 13843 (accession number KU219481) (Fig. 1).

Previous reports showed evidence that clinical disease in cats is rare [3, 7, 8]. The antibiotic therapy was defined in two stages. During the first stage, the cat was treated with amoxicillin, $20 \mathrm{mg} / \mathrm{kg} / \mathrm{BID}$ orally for 12 days. During the second stage it was treated with doxyciclyne, $10 \mathrm{mg} / \mathrm{kg}$ orally/24 hr for 2 weeks. After first (at days 12 and 26) and second treatment stage (at day 60), urine samples were negative to PCR and culture.

Evidence of cat exposure to Leptospira spp. has already been described $[5,10,12,15]$. In cats, low antibody titers against Leptospira spp. have been reported [4, 13], ranging from 1:30 to 1:400. The positive urine culture (confirmed by qPCR) is a 


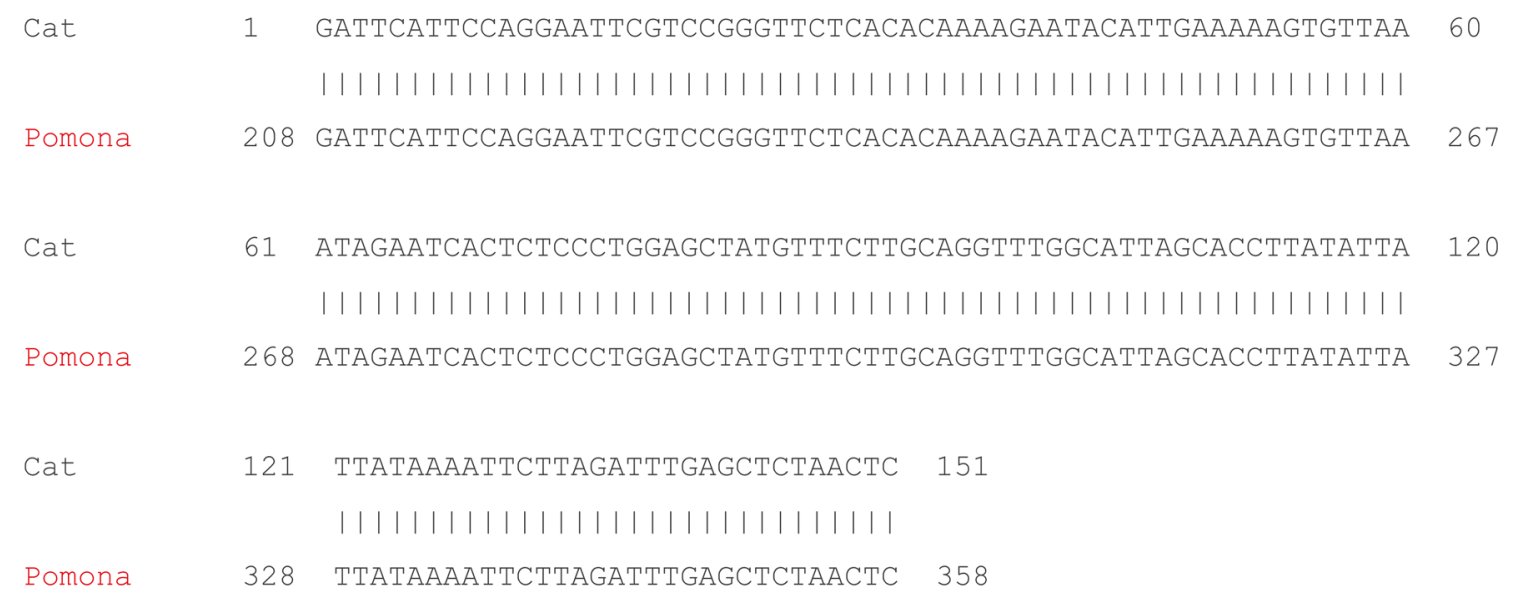

Fig. 1. ClustalW aligment for 151 bp fragment, $\operatorname{Sec} Y$ gene with Leptospira interrogans serovar Pomona strain 13843 protein translocase subunit $\operatorname{Sec} Y(\sec Y)$ gene, partial cds (Sequence ID: KU219481.1).

strong evidence of active infection. In addition, the high antibody titers suggest that the cat was exposured. For Rodriguez et al. (2014), these high antibody titers could be associated to an efficient humoral response that may reflect different infectious statuses, especially in outdoor cats.

The subclinical presentation observed in this case suggests that feline leptospirosis has been underdiagnosed in the feline population, particularly in cats that live close to primary reservoirs such as livestock $[5,15]$.

Although direct causality was not addressed in this study, the source of infection is speculated to be dairy cattle sharing the same environment with the cat, as the cat lives in close contact with cattle, especially in the calf rearing facilities. Additionally, during the sampling for the present study, it was possible to verify that biosecurity measures were not respected systematically favouring Leptospira infection transmission. The term 'close contact' refers to the cat sleeping where the calves were kept. These calf pens had very wet straw bedding, mainly because of urine. Additionally, the cat was fed with milk from the same cattle herd. Due to the active rodent hunter behaviour of the patient, rodents can't be excluded according to the informed serovars. It has been hypothesised that prey-predator transmission between cats and rodents is responsible for infections with serovars copenhageni and ballum [18]. Infections with the other serovars are presumed to result from contact with infected animals or a contaminated environment [18]. Future studies in the farm, might indicate which species are acting as reservoirs.

According to many studies with antibody testing, it is not clear what the most frequent serovar in cats are. However, as in the present study, some authors have reported Pomona as the most prevalent serovar detected [15, 17]; in others Autumnalis was the most prevalent [12]. In a recent study in the same area as the cat inhabits, the most frequent serovars detected were Autumnalis, Canicola, and Batavie [4], but no cats with clinical signs were observed. On the other hand, Chan et al. (2014) sampled serum and urine from 238 cats without clinical signs. Using MAT and PCR the serovars detected were Icterohaemorrhagiae, Shermani, Australis, Javanica and Kirchneri. The study did not detect Pomona, Panama, Autumnalis, Canicola, Bataviae, and Tarassovi.

In dogs, Pomona serovar has been associated with severe liver dysfunction [7, 9], which was not observed in our patient.

Pomona serovar has been previously informed as highly frequent in dairy cattle herds in southern Chile [16, 22], and it has been found consistently in high prevalence in the cattle herd where the cat lives.

If the cat is a dead-end host, treatment of infected cats could be an important component for Leptospira spp. infection control, given the excretion of the bacteria to the environment, thus, contributing to new infection either to animals or humans.

This report expands the diversity of host species that can become actively infected by Leptospira spp. Whether an infected domestic cat that dwells within a dairy farm represents a risk of Leptospira infection for livestock or humans remains to be determined.

This report also evidenced an effective antibiotic treatment to eliminate the Leptospira infection in cats. There was no association between serological and bacteriological information reported with any clinical sign. The epidemiological importance of feline leptospirosis must be evaluated again due to its zoonotic nature.

CONFLICT OF INTEREST. The authors declare no conflict of interest.

ACKNOWLEDGMENT. This work was supported by FONDECYT grant (1141070). 


\section{REFERENCES}

1. Adin, C. A. and Cowgill, L. D. 2000. Treatment and outcome of dogs with leptospirosis: 36 cases (1990-1998). J. Am. Vet. Med. Assoc. 216: 371-375. [Medline] [CrossRef]

2. Ahmed, A., Engelberts, M. F., Boer, K. R., Ahmed, N. and Hartskeerl, R. A. 2009. Development and validation of a real-time PCR for detection of pathogenic leptospira species in clinical materials. PLoS One 4: e7093-e7120. [Medline] [CrossRef]

3. Arbour, J., Blais, M. C., Carioto, L. and Sylvestre, D. 2012. Clinical leptospirosis in three cats (2001-2009). J. Am. Anim. Hosp. Assoc. 48: 256-260. [Medline] [CrossRef]

4. Azócar-Aedo, L., Monti, G. and Jara, R. 2014. Leptospira spp. in domestic cats from different environments: prevalence of antibodies and risk factors associated with the seropositivity. Animals (Basel) 4: 612-626. [Medline] [CrossRef]

5. Chan, K. W., Hsu, Y. H., Hu, W. L., Pan, M. J., Lai, J. M., Huang, K. C. and Chou, S. J. 2014. Serological and PCR detection of feline leptospira in southern Taiwan. Vector Borne Zoonotic Dis. 14: 118-123. [Medline] [CrossRef]

6. Faine, S., Adler, B., Bolin, C. and Perolat, P. 1999. Leptospira and leptospirosis. pp. 131-143. In: Leptospira and Leptospirosis (Faine, S., Adler, B., Bolin, C. and Perolat, P. eds.), Medisci Press, Melbourne.

7. Green, C., Sykes, J., Moon, G., Goldstein, R. and Schultz, R. 2011. Leptospirosis. pp. 431-446. In: Infectious in Dogs and Cats (Green, C. ed.), Saunders, St. Louis.

8. Hartmann, K., Egberink, H., Pennisi, M. G., Lloret, A., Addie, D., Belák, S., Boucraut-Baralon, C., Frymus, T., Gruffydd-Jones, T., Hosie, M. J., Lutz, H., Marsilio, F., Möstl, K., Radford, A. D., Thiry, E., Truyen, U. and Horzinek, M. C. 2013. Leptospira species infection in cats: ABCD guidelines on prevention and management. J. Feline Med. Surg. 15: 576-581. [Medline] [CrossRef]

9. Langston, C. E. and Heuter, K. J. 2003. Leptospirosis. A re-emerging zoonotic disease. Vet. Clin. North Am. Small Anim. Pract. 33: $791-807$. [Medline] [CrossRef]

10. Lapointe, C., Plamondon, I. and Dunn, M. 2013. Feline leptospirosis serosurvey from a Quebec referral hospital. Can. Vet. J. 54: 497-499. [Medline]

11. Levett, P. N. L. 2001. Leptospirosis. Clin. Microbiol. Rev. 14: 296-326. [Medline] [CrossRef]

12. Markovich, J. E., Ross, L. and McCobb, E. 2012. The prevalence of leptospiral antibodies in free roaming cats in Worcester County, Massachusetts. J. Vet. Intern. Med. 26: 688-689. [Medline] [CrossRef]

13. Mylonakis, M. E., Bourtzi-Hatzopoulou, E., Koutinas, A. F., Petridou, E., Saridomichelakis, M. N., Leontides, L. and Siochu, A. 2005. Leptospiral seroepidemiology in a feline hospital population in Greece. Vet. Rec. 156: 615-616. [Medline] [CrossRef]

14. Riedemann, S., Leal, H. and Zamora, J. 1986. Diagnóstico serológico de Leptospirosis bovina en cuatro regiones de Chile. Arch. Med. Vet. 18: $129-133$.

15. Rodriguez, J., Blais, M. C., Lapointe, C., Arsenault, J., Carioto, L. and Harel, J. 2014. Serologic and urinary PCR survey of leptospirosis in healthy cats and in cats with kidney disease. J. Vet. Intern. Med. 28: 284-293. [Medline] [CrossRef]

16. Salgado, M., Otto, B., Sandoval, E., Reinhardt, G. and Boqvist, S. 2014. A cross sectional observational study to estimate herd level risk factors for Leptospira spp. serovars in small holder dairy cattle farms in southern Chile. BMC Vet. Res. 10: 126-132. [Medline] [CrossRef]

17. Sessions, J. and Greene, C. 2004. Canine Leptospirosis: Epidemiology, Pathogenesis, and Diagnosis. Compend. Cont. Educ. Pract. 26: 606-622.

18. Shophet, R. 1979. A serological survey of leptospirosis in cats. N. Z. Vet. J. 27: 236-245, 245-246. [Medline] [CrossRef]

19. Stoddard, R. A., Gee, J. E., Wilkins, P. P., McCaustland, K. and Hoffmaster, A. R. 2009. Detection of pathogenic Leptospira spp. through TaqMan polymerase chain reaction targeting the LipL32 gene. Diagn. Microbiol. Infect. Dis. 64: 247-255. [Medline] [CrossRef]

20. Sykes, J. E., Hartmann, K., Lunn, K. F., Moore, G. E., Stoddard, R. A. and Goldstein, R. E. 2011. 2010 ACVIM small animal consensus statement on leptospirosis: diagnosis, epidemiology, treatment, and prevention. J. Vet. Intern. Med. 25: 1-13. [Medline] [CrossRef]

21. Suputtamongkol, Y., Pongtavornpinyo, W., Lubell, Y., Suttinont, C., Hoontrakul, S., Phimda, K., Losuwanaluk, K., Suwancharoen, D., Silpasakorn, S., Chierakul, W. and Day, N. 2010. Strategies for diagnosis and treatment of suspected leptospirosis: a cost-benefit analysis. PLoS Negl. Trop. Dis. 4: e610-e627. [Medline] [CrossRef]

22. Truccolo, J., Charavay, F., Merien, F. and Perolat, P. 2002. Quantitative PCR assay to evaluate ampicillin, ofloxacin, and doxycycline for treatment of experimental leptospirosis. Antimicrob. Agents Chemother. 46: 848-853. [Medline] [CrossRef]

23. Zamora, J., Riedemann, S., Montesinos, M. and Cabezas, X. 1991. Aislamiento en Chile de Leptospira interrogans serovares hardjo y kennewicki en bovinos aparentemente sanos. Arch. Med. Vet. 23: 131-134.

24. Zamora, J. and Riedemann, S. 1999. Animales silvestres como reservorios de Leptospirosis en Chile. Una revisión de los estudios efectuados en el país. Arch. Med. Vet. 31: 151-156. [CrossRef]

25. Zuerner, R. L. and Bolin, C. A. 1997. Differentiation of Leptospira interrogans isolates by IS1500 hybridization and PCR assays. J. Clin. Microbiol. 35: 2612-2617. [Medline] 